\title{
Development of Learning and Feedback Giving Skills in Home Economics and Technologies Education
}

\author{
Aija Pridane Dr. paed. \\ Latvia University of Life Sciences and Technologies \\ Institute of Education and Home Economics, Latvia \\ aija_pridane@inbox.lv
}

\begin{abstract}
The article highlights the necessity for self-directed learning and feedback skills in development of pupils' learning. They so far have not received enough attention in the content of the curriculum. Using the lessons learned in pedagogical studies, it is grounded that learning to learn does not only make it possible for Home Economics to learn, but also in any area of life, in all contexts, and it has a significant impact on learning progress and achievement. The aim of the research is to evaluate the pupils' learning skills of 6th-8th grade Jelgava Secondary school N4 in Home Economics and Technologies program Textiles according to the theoretical knowledge and conclusions. The research used methods of questioning, data mathematical processing and evaluation. The results of the survey show that the students have generally good learning skills and show specific aspects of improving them. The example of feedback in this article while learning the subject on How to Knit an Item provides information for the teacher how to organize the learning process effectively for improving pupils' learning skills.
\end{abstract}

Keywords: learning skills, feedback, Home Economics and Technologies, primary school education.

\section{Introduction}

Educational Reforms The school in 2030 radically reverse the approach to teaching, with the emphasis on student performance and their ability to do so, thus gaining the competencies required in the $21^{\text {st }}$ century. A. Schleicher argued that the key to the success of a school graduate is not the amount of knowledge gained, but what he can do with his knowledge (Kompetenci attistosa macisanas..., 2017).

The author's experience suggests that, despite the fact that the aspects, which correspond to intracontextual link among the subjects, including Learning to learn skills development, have already been formulated already in 1998 in educational standards of Latvia, the lesson observation and analysis, as well the analysis of student performance show that it is not a routine practice in all schools (Namsone, 2015). Therefore, the goal of education reform is a school that supports the learning of each student and implements learning through an in-depth approach. It is taught by everyone: students, teachers, school management and other staff (Izglitiba musdienigai lietpratibai..., 2017, 16).

Studies by pedagogues suggest that self-directed learning skills have a significant impact on academic achievement. Not in vain J.S. Bruner sees the "learn how to learn" skill as a key to learning (Bruner, 1960).

Learning is a process in which an individual acquires knowledge, skills, attitudes, and improves his or her experience. Learning is a purposefully organized activity, on the basis of which simultaneously a statement is developed. It is an important engine of human and life development, an interest in life, a key to the quality of life of an individual (Holzkamp, 1995). In this context, in the context of learning, R. Saljo (1979) and F. Marton, G. Dall'Alba, E. Beatty (1993) talk about the accumulation of knowledge, the use of information, memorization, the acquisition of various skills, techniques and facts so that they can be used when needed.

In the context of lifelong learning, learning to learn is defined as the ability to undertake, organize and continue learning, effectively planning time and information, acquiring new knowledge and skills. This is the process of information processing in the interaction between the already learned (existing knowledge) and the new information (subject of learning) which is not yet known. Learning is always the first person to learn and I have my own reasons for it. It is an understanding of your learning and thinking process and needs, to complement previous knowledge and life experiences to use in a variety of contexts: at home, at work, in education and throughout life (Key Competences of Lifelong..., 2018).

In all cases, learning to learn requires a learner to be familiar with the learning strategies chosen for learning purposes, to be able to plan his or her learning, to organize and regulate it, to evaluate his or her success, 
the strengths and weaknesses of his knowledge and skills, the causes of success and failure. Likewise, the student must be able to work with others, gain and share their knowledge, seek support if necessary.

Learning skills can be developed because a person, through learning and cognition, constructs his own understanding of things and the world by himself. J.S. suggested that schools use the discovery of learning more often when students formulate training hypotheses, test them on their own, rather than simply accept the teacher's statements as indisputable truth (Bruner, 1960). Learning will only take place when the subject is considered to be meaningful and personally relevant to the learner himself, and when the student actively participates in learning and learning (Mayer, Wittrosk, 1996).

In order to develop pupils' learning to learn skills, a teacher has to link the strategies of learning with the content in a particular way, since self-directed learning is better in a specific area (Perels, Guertler, Schmitz, 2005). It is also necessary to provide a supportive learning environment for students, where they can train self-directed thinking (Van Hout-Wolters, Simons, Volet, 2000) and the use of learning skills in all areas (Fuchs, 2003). Progress and the improvement of learning outcomes depend on the student's ability to adjust his or her pace and performance to a specific, long-term goal.

Effective learning will occur if there is a partnership between teachers and pupils where the students will gradually learn to lead their learning by themselves, the goals and tools for measuring the results achieved there will be defined clearly. This will happen if the teacher is clear about organizing the study process (lessons); what the students learned during the lesson (during the course of the topic); how the teacher will find out what the result is achieved per lesson (during the course of the topic); how students can understand what they have learned in the lesson (during the course of the topic).

As a result of student learning skills improvement, they should be able to decide by themselves: how to divide a complex task into smaller ones, how to choose the methods and tools to be used; when to set the time frame, deadlines; which responsibilities are shared and which are not; where to decide, what tasks to do in the classroom at home elsewhere in the process of planning their own learning.

Pupils' learning habits should be linked to the organization of the learning process, parts (of the subject cquisition) of the lessons, planning, monitoring and evaluation (Schraw, Dennison, 1994). At the stage of updating the subject, the student prepares for learning, meaning learning planning (goal setting, strategic decision making, self-efficacy, natural interest).

Planning is when, thinking about the meaningful result, you are looking for answers to questions as I know that it's achieved, what should I do to achieve it. In the second stage, learning is an important learning process - monitoring, learning step-by-step (self-study, focus, maintenance of internal requirements, time scheduling, search support, self-monitoring, self-generated sequencing system). In turn, in the third stage, the feedback gives an understanding of what the student learned - assessment I understand what I learned (causation and consequence analysis, adaptation).

Another essential requirement for the development of learning skills is the constant and effective feedback in the context of the goals set (Wiggins, 2012). Feedback is information about what the student is doing towards the goal, assessment or recommendations for improving performance-performance (Hattie, Yates, 2014). Feedback is required at all stages of the learning curriculum. Studies have shown that learning less, giving more feedback, can lead to better learning (Bransford, Brown, Cocking, 2000; Hattie, 2011; Marzano, Pickering, Pollock, 2001). In this context, it is important to have less feedback from the teacher, but more about the student's own activities.

The aim of the research is to evaluate the pupils' learning skills of 6th-8th grade Jelgava Secondary school N4 in Home Economics and Technologies program Textiles according to the theoretical knowledge and conclusions.

\section{Methodology}

The study is based on the findings of the need for self-directed learning, developing student learning and feedback skills. In the first part of the study, a questionnaire was organized to familiarize students with the learning habits. The self-assessment criteria for students' learning habits in Home Economics and Technology (Table 1) were based on the materials of School 2030 (Schraw, Dennison, 1994; Izglitiba musdienigai lietpratibai..., 2017). 
The study took place in Jelgava Secondary School No. 4 in the framework of the Textile program in December 2017. A total of 35 schoolchildren from grades 6 to 8 were interviewed.

The questionnaire included 24 questions, arranged in 3 parts.

-1-10 question-planning part (preparation for learning);

-11-19 question-monitoring part (learning);

- 20-24 question - part of evaluation (understanding what learning is learning).

Schoolchildren had to assess their learning habits on three positions: yes, no, sometimes.

In the second part of the research, opportunities were sought for using home-school education through feedback, developing and improving pupil's learning skills, especially in technology acquisition. The author believes that adequate feedback helps schoolchildren learn to learn about the process of handicraft and the making objects, to improve their creative experience.

Questionnaire was prepared based on the questions raised by G. Schraw and R.S. Dennison (1994) assessing metacognitive awareness for each stage of the learning curriculum (planning, monitoring, evaluation). An example of the feedback is shown in Table 2 on topic How to Knit an Item over.

\section{Results and Discussion}

The results of the study presented in Table 1 are analyzed below. Generally good results can be observed in the first part of learning the content - in the part of planning. Almost every student responded that the teacher would recall what has already been taught and what will be necessary for the lesson $(91,5 \%)$, that the time for self-study and thinking is given $(80 \%)$, and that the content to be learned and objectives to be achieved are clear. Seventy-seven commas two percent $(77,2 \%)$ schoolchildren understand that the learning objectives help to achieve the goal of the lesson.

In the second part - monitoring - almost all schoolgirls- $80 \%$, sometimes- $11,4 \%$, admit that they have the opportunity to improve their accomplishments, improve their knowledge and skills. Mostly, 68,5\% students recognize that they have the opportunity to work together with their classmates during the lesson. Also, the most part $(68,6 \%)$ of the respondents confirm that the teacher provides them with the information on where and how to do additional practice and learning better, in case they have a desire to study the subject thoroughly.

The answers to question 18, on the other hand, suggest that the teacher should pay more attention to providing the necessary feedback, as only 34,3 schoolchildren approve, and 45,7\% schoolchildren sometimes admit that they receive information from the teacher about their learning outcomes at the end of the lesson or a subject. The survey shows that co-operation with classmates help to learn better in $54,3 \%$, sometimes $28,6 \%$, as well as half the girls $57,2 \%$ like, but $25,7 \%$ sometimes like working in groups. Further, my wish is that my students would have a stronger desire to study the subject in depth. Questions 16 indicates that $42,8 \%$ girls are motivated, but $25,7 \%$ only sometimes are motivated to look for additional information on the Internet or in other sources of information (magazines, books).

The results of the third part - evaluation - show that the teacher's assessment of the learning outcomes is objective (77,2\%-yes, $20 \%$ - sometimes). The respondents feel that they can notice and evaluate their learning habits by themselves (68,6\%-yes, $20 \%$ - sometimes). However, the clear desire to improve their learning outcomes in Home Economics and Technologies is expressed only by a half of the schoolgirls $(51,4 \%)$, sometimes - by $45,7 \%$ students. Perhaps, this is because the Home Economics and Technologies semester marks and total marks of the year are relatively higher than the marks in other subjects.

Answers to Question 21 show that there is a lack of the students' $(42,8 \%)$ recommendation skills to improve their classmates' learning outcomes. Lesson observations show that these skills are limited to some girls in the classroom. By learning to provide an effective feedback, the ability to give advice to their classmates might also be developed for the students' learning habits.

Generally, the case study shows that the learning skills of the schoolgirls are well developed. The negative answers are in the range from $2.8 \%$ to $11.4 \%$. It is about one tenth. The students 'answers to the questions reveal specific aspects of the development of learning skills for the teacher: to improve the methodology of motivating the interest, the students' ability to formulate, ask questions, improve the study 
materials, provide them with information about the possibilities for in-depth study of the substance, and develop cooperation skills in order to give recommendations to classmates.

Table 1

Self - Evaluation of Students' Learning Habits in Achieving Education

in Home Economics and Technologies (number of students $n=35$, answers in \%)

\begin{tabular}{|c|c|c|c|c|}
\hline $\begin{array}{c}\text { AS } \\
\text { parts }\end{array}$ & Criteria - how students learn & Yes & No & Sometimes \\
\hline \multirow{10}{*}{ 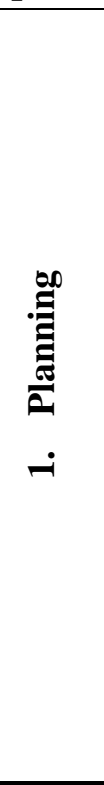 } & 1. I understand the goal that has to be achieved & 77,2 & 2,8 & 20 \\
\hline & 2. I know learning will be exciting, interesting & 45,7 & 17,1 & 37,2 \\
\hline & $\begin{array}{l}\text { 3. Teacher recalls what has already been taught and what will } \\
\text { be necessary for the lesson }\end{array}$ & 91,5 & 5,6 & 2,9 \\
\hline & $\begin{array}{l}\text { 4. It is clear to me what has to be done and how to do the } \\
\text { training }\end{array}$ & 51,6 & 5,6 & 42,8 \\
\hline & $\begin{array}{l}\text { 5. It is clear to me which learning objectives help to achieve the } \\
\text { aim of the lesson }\end{array}$ & 65,7 & 11,4 & 22,9 \\
\hline & $\begin{array}{l}\text { 6. I have been given the time for self-study and thinking in the } \\
\text { lesson }\end{array}$ & 80 & 2,9 & 17,1 \\
\hline & $\begin{array}{l}\text { 7. The learning tasks are interesting and practical for everyday } \\
\text { life }\end{array}$ & 45,7 & 5,6 & 48,7 \\
\hline & $\begin{array}{l}\text { 8. I have been given time for training and practicing in the } \\
\text { lesson }\end{array}$ & 51,4 & 17,1 & 31,5 \\
\hline & 9. I can ask and consult if necessary & 57,2 & 0 & $\mathbf{4 2 , 8}$ \\
\hline & $\begin{array}{l}\text { 10. I can express my opinion, offer my ideas on how the aim of } \\
\text { the lesson can better be achieved }\end{array}$ & 57,2 & 17,1 & 25,7 \\
\hline \multirow{9}{*}{ 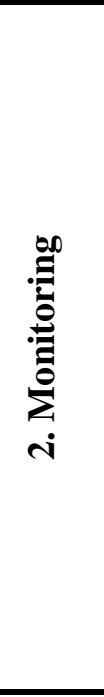 } & $\begin{array}{l}\text { 11. I have been given the possibility to cooperate with my } \\
\text { classmates }\end{array}$ & 68,5 & 5,8 & 25,7 \\
\hline & 12. Cooperation with my classmates helps me to learn better & 54,3 & 17,1 & 28,6 \\
\hline & 13. I enjoy working in groups & 57,2 & 17,1 & 25,7 \\
\hline & 14. The teacher supports me in my learning & 65,8 & 14,2 & 20 \\
\hline & 15. I use varioust sources in preparation for the lessons & 51,4 & 11,4 & 37,2 \\
\hline & $\begin{array}{l}\text { 16. Interest in the subject being taught is motivating me to seek } \\
\text { additional information on the Internet or in other sources of } \\
\text { information (magazines, books) }\end{array}$ & 42,8 & 31,5 & 25,7 \\
\hline & $\begin{array}{l}\text { 17. The teacher has given me information where and how to do } \\
\text { it better, if I want to learn a subject in depth. }\end{array}$ & 68,6 & 2,8 & 28,6 \\
\hline & $\begin{array}{l}\text { 18. I receive information from the teacher about my learning } \\
\text { outcomes at the end of the lesson and at the end of the topic. }\end{array}$ & 34,3 & 20 & $\mathbf{4 5 , 7}$ \\
\hline & $\begin{array}{l}\text { 19. I have the opportunity to improve the work done, to improve } \\
\text { my knowledge and skills }\end{array}$ & 80 & 8,6 & 11,4 \\
\hline \multirow{5}{*}{ 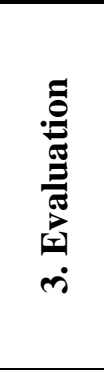 } & 20. I can see, evaluate my learning habits & 68,6 & 11,4 & 20 \\
\hline & $\begin{array}{l}\text { 21. I am able to recommend my classmates how to improve their } \\
\text { learning outcomes (knowledge and skills). }\end{array}$ & 42,8 & 28,6 & 28,6 \\
\hline & $\begin{array}{l}\text { 22. I have a desire to improve my learning outcomes in Home } \\
\text { Economics and Technology }\end{array}$ & 51,4 & 2,9 & 45,7 \\
\hline & $\begin{array}{l}\text { 23. I regularly prepare for Home Economics and Technology } \\
\text { lessons and am actively involved in them }\end{array}$ & 40 & 11,4 & 48,6 \\
\hline & 24. Assessment of learning outcomes by the teacher is objective & $\mathbf{7 7 , 2}$ & 2,8 & 20 \\
\hline
\end{tabular}

Adapted from (Schraw, Dennison, 1994)

The example in the Tabele 2 is based on the theoretical lessons about the relevance of the feedback in the learning process. 
In Home Economic and Technologies lessons, students have to evaluate themselves on regular bases about the process of learning according to the goal - which is to form a general understanding about knitting a sock and get practical experience in it. The example of the feedback given in the article can be used in parts, preferably in each stage of the learning in the lesson (topic) as a self-assessment. The questions make the students think about their own learning habits, the ability to manage their learning according to the plan and how one can carry out the idea of a knitted pair of socks to the real-life situation. Schoolgirls also learn to evaluate the effectiveness of their activities - the methodology and techniques for acquiring the knitting technology, the criteria for assessing the quality of the knitted item and the evaluation of their performance in relation to the intended result to be achieved. The example of the feedback given in the article can be used in parts, preferably in each stage of the learning lesson (topic) as a self-assessment. It can be done both - in writing and orally.

Table 2

\section{An Example of Feedback about Learning the Subject How to Knit an Item}

\begin{tabular}{|c|c|}
\hline 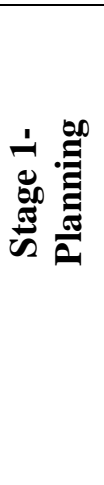 & $\begin{array}{l}\text { 1. Was it clear to you which knowledge and skills would be necessary for reaching the } \\
\text { result - a pair of self knitted socks, before you started knitting? } \\
\text { 2. What were your feelings before the work started? } \\
\text { - I have the necessary ability; } \\
\text { - I know that it will not be easy, but I am going to do it; } \\
\text { - The teacher is asking too much from me; } \\
\text { - I do not need it and I do not want to do it; } \\
\text { - another variant ... } \\
\text { 3. I had the opportunity to choose the type and size of the sock according to me } \\
\text { Own skills: Yes/ No/ Why? } \\
\text { 4. I was aware of the knitting period section, before I started my work. Yes/No }\end{array}$ \\
\hline 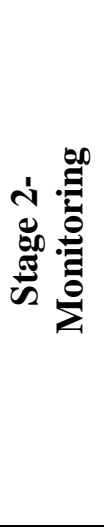 & $\begin{array}{l}\text { 1. What preparations did you make before knitting a sock? } \\
\text { 2. What kind of help did you use to make socks during knitting } \\
\text { - a worksheet developed by the teacher; } \\
\text { - I did (practiced, tried) with the teacher and classmates per hour; } \\
\text { - I use information from books; } \\
\text { - I use information on Internet resources; } \\
\text { - I attend individual teacher consultations; } \\
\text { - I use my mother or someone else's help; } \\
\text { - I use classmates' help; } \\
\text { - another version ....... } \\
\text { 3. I asked, consulted, and verified my activities, correctness, in the process of } \\
\text { knitting a sock: Yes/No/ Why? }\end{array}$ \\
\hline 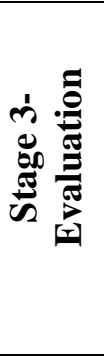 & $\begin{array}{l}\text { Which stages did you have difficulty in? } \\
\text { 1. How did you deal with the difficulties of knitting a sock? } \\
\text { 2. Did you fit into the teacher's deadlines: } \\
\quad \text { - during knitting the first sock: Yes/ No/ Why? .... } \\
\text { - during knitting the second sock: Yes/ No/Why? .... } \\
\text { 3. How did you plan your work? .... } \\
\text { 4. Did you ask for advice on how to improve your performance after you started knitting } \\
\text { the first and the second sock? Who were they? }\end{array}$ \\
\hline
\end{tabular}

In turn, the teacher can use the information obtained to improve or adapt the learning content methodology, to specify the learning tasks in the context of the result to be achieved.

\section{Conclusions}

1. Learning to learn have a significant impact on academic achievement and in relation to educational objectives means:

- to acquire and use information and knowledge, to use and accumulate, to learn the methods and skills of the operation,

- to develop attitudes, to improve their experience, to motivate life-long education;

- to know the chosen learning strategies; 
- be able to plan to organize and regulate your learning;

- to assess own progress, strengths and weaknesses of knowledge and skills, successes and cause of failures;

- ability to collaborate with others, gain and share their knowledge;

- seek support if necessary.

2. Learning skills can be developed if person constructs his/her own understanding of things and the world through learning and cognition by himself. Students' ability to effectively learn, gives them the opportunity to acquire knowledge and skills not only in-home economics education, but also in any field of life, in any context.

3. In order to improve students' learning skills, the teacher needs feedback on the progress of the learning process and the acquisition of the content, the students' level of knowledge and skills.

4. The main precondition for the development of learning skills is a constant and effective feedback in the context of the result (goal) to be achieved. The feedback is needed at all stages of the learning curriculum and provides answers to questions about the planning, monitoring, assessment of students' learning.

5. Studies of the theme Textiles in Home Economics and Technology classes at Jelgava Secondary School N4 show that students' learning skills are in a good condition. Similarly, the answers to questions show some specific aspects of the development of the learning skills. The example of a feedback, given in the article, while learning the subject How to Knit an Item, provides a teacher with the information on how organize the learning process effectively for improving the student's learning skills.

6. The students' answers to the questions reveal specific aspects of the development of learning skills for the teacher:

- to improve the methodology of motivating the interest;

- the students' ability to formulate and ask questions;

- to improve the study materials, provide them with information about the possibilities for in-depth study of the substance;

- to develop cooperation skills in order to give recommendations to classmates.

\section{Bibliography}

1. Bransford J.D., Brown A.L., Cocking R.R. (Eds.). (2000). How people learn: Brain, mind, experience and school. Washington, DC: National Academy Press.

2. Bruner J.S. (1960). The Process of education. Cambridge, Mass: Hardvard University, Press. Retrieved from http://edci770.pbworks.com/w/file/fetch/45494576/Bruner_Processes_of_Education.pdf

3. Fuchs L.S. (2003). Assessing Intervention Responsiveness: Conceptual and Technical Issues. In L.H. Mason (Ed.), Learning Disabilities Research and Practice, 18(3), 172-186. Retrieved from http://onlinelibrary.wiley.com/doi/10.1111/1540-5826.00073/full

4. Hattie J., Yates G.C.R. (2014). Visible Learning and the Science of How We Learn. London and New York: Routledge.

5. Hattie J. (2011). Visible learning: A synthesis of over 800 meta-analyses relating to achievement. Internatioanl Review of Education, 8. Abingdon, New York: Routledge.

6. Izglitiba musdienigai lietpratibai: macibu satura un pieejas apraksts (Education for Modern Competence: Description of Study Content and Approach). (2017). Riga: VISC, Eiropas sociālais fonds. Retrieved from https://domaundari.lv/cepure/Jauna satura ietvars.pdf (in Latvian)

7. Key Competences of Lifelong Learning. (2018). Brussels: European Commission. Retrieved from https://ec.europa.eu/education/sites/education/files/swd-recommendation-key-competenceslifelong-learning.pdf

8. Kompetenci attistosa macisanas. Ieteikumi izglitibas politikas un ricibpolitikas veidotajiem (Competence-based learning. Recommendations for Education Policy and Policy Makers). (2017). Riga: LU, Starpnozaru izglitibas inovāciju centrs. Retrieved from www.telerehabilitation.lv/lv/node/146 (in Latvian) 
9. Marton F., Dall'Alba G., Beatty E. (1993). Conceptions of Learning. International Journal of Educational Research, 19, 277-300.

10. Marzano R.J., Pickering D.J., Pollock J.E. (2001). Classroom Instruction that Works: ResearchBased Strategies for Increasing Student Achievement. Alexandria, VA: ASCD.

11. Mayer R.E., Wittrosk M.C. (1996). Problem Solving Transfer. In D.C. Berliner, R.C. Calfee (Eds.), Handbook of Educational Psychology. New York: Macmillan, 47-62.

12. Namsone D. (2015). How the Absence of Higher PISA Scores is Connected with Science Classroom? Riga: LU. Retrieved form https://www.siic.lu.lv/fileadmin/user_upload/lu_portal/projekti/siic/Publikacijas/Materiali_VPP/3 Cyprus_presentation_PISA_2015.pdf

13. Perels, F., Guertler, T., Schmitz, B. (2005). Training of self-regulatory and problem-solving competence. Learning and Instruction, 15, 123-139.

14. Saljo R. (1979). Learning in the Learner's Perspective: I. Some Common-Sense Conceptions No 76. Sweden: Gothenburg University.

15. Schraw G., Dennison R.S. (1994). Assessing Metacognitive Awareness. Contemporary Educational Psychology, 19(4), 460-475.

16. Van Hout-Wolters B., Simons R.J., Volet S. (2000). Active Learning: Self-Directed Learning and Independent Work. In R.J. Simons, J. van der Linden, T. Duffy (Eds.), New Learning. Dordrecht: Kluwer Academic Publishers, 21-36.

17. Wiggins G. (2012). Seven Keys to Effective Feedback. Educational Leadership, 70(1), 10-16. Retrieved from http://www.ascd.org/publications/educationalleadership/sept12/vol70/num01/Seven Keys-to-Effective-Feedback.aspx 